\title{
Looking West: Understanding Socio-Political Allegories and Art References in Contemporary Romanian Cinema
}

\author{
Hajnal Király \\ Research Fellow, Eötvös Loránd University (Budapest), \\ Sapientia Hungarian University of Transylvania (Cluj-Napoca, Romania) \\ E-mail: hajnal.kiraly@gmail.com
}

\begin{abstract}
The representation of other arts in cinema can be regarded as a different semiotic system revealing what is hidden in the narrative, as a site of cultural meanings inherent to the cinematic apparatus addressing a pensive spectator, or a discourse on cinema born in the space of intermediality. In the post-1989 films of Romanian director Lucian Pintilie, painterly and sculptural references, as well as miniatures become figurations of cultural identity inside allegories about a society torn between East and West. I argue that art references are liberating these films from provincialism by transforming them into a discourse lamenting over the loss of Western, Christian and local values, endangered or forgotten in the post-communist era. In the films under analysis - An Unforgettable Summer (1994), Too Late (1996) and Tertium Non Datur (2006) - images reminding of Byzantine iconography, together with direct references and remediations of sculptures by Romanian-born Constantin Brâncuşi, participate in historico-political allegories as expressions of social crisis and the transient nature of values. They also reveal the tension between an external and internal image of Romania, the aspiration of the "other Europe" to connect with the European cultural tradition, in a complex demonstration of a "self-othering" process. I will also argue that, contrary to the existing criticism, this generalizing, allegorical tendency can also be detected in some of the films of the generation of filmmakers representing the New Romanian Cinema, for example in Radu Jude's Aferim! (2015). ${ }^{1}$
\end{abstract}

Keywords: allegory, figuration, mimicry, miniature, Lucian Pintilie.

\section{The Time of Historical Allegories}

The tendency of allegorization in cinema has been commonly regarded by the new generations of filmmakers and critics as an obsolete means of figuration

1 This work was supported by a grant of the Romanian Ministry of National Education, CNCS UEFISCDI, project number PN-II-ID-PCE-2012-4-0573. 
that effaces burning socio-political questions. National, historical allegories are seen as belonging to the declining project of modernity that once propagated belief in progress, national identity and nation states. Temenuga Trifonova in her analysis of post-communist Bulgarian cinema talks about a "weak" national cinema that, under the circumstances of extensive transnational movements, still holds to an allegorical expressionism "which is challenged only occasionally by less provincial styles of film-making" $(2015,128)$. As she argues, this type of figuration characterizes by simplicity, transparency and "a self-imposed limit on the meaning one wants to convey and the means one believes are necessary (or sufficient) to convey it" $(2015,129)$. Without, however, elaborating on the theoretical background of such cinematic discourse, she dismisses it as "provincial" on the basis of a surface and hidden meaning duality that targets a narrow public familiar with it on the level of the narrative and not that of the visual representation $(2015,130-131)$. In Romania, the rejection of an allegorical, cinematic language by the directors of the so-called New Romanian Cinema or Romanian New Wave ${ }^{2}$ appears more as a generational attitude towards a highly figurative trend in the 1990s, represented by the films of old masters like Mircea Daneliuc and Lucian Pintilie. This attitude is all the more paradoxical because it coexists with a certain reverence for emblematic films of these two directors, such as Reconstruction (Reconstituirea, Lucian Pintilie, 1968) and Microphone Test (Probă de microfon, Mircea Daneliuc, 1980), both marked by a tendency of allegorical signification. Moreover, critics have detected mildly allegorizing tendencies in some of the films of this new generation, such as The Death of Mr. Lăzărescu (Moartea domnului Lăzărescu, Cristi Puiu, 2005) and the films of Cristian Mungiu (4 Months, 3 Weeks, 2 Days [4 luni, 3 săptămâni, 2 zile], 2007 and Beyond the Hills [După dealuri], 2012) that epitomize a neutral, metaphorical, generalizing approach to the events presented. ${ }^{3}$ As I will argue

2 The denomination of this group of directors as representing a New Cinema or a Romanian New Wave has been largely debated by critics and the directors themselves. According to Andrei Gorzo, the first refers to a series of stylistic features shared by a number of internationally acclaimed films that became a mainstream style in contemporary Romanian cinematography, while the second defines simply a generation of successful directors. According to Gorzo, the Puiu-Mungiu-Muntean line is not completely fulfilling the conditions of a New Wave in the sense consecrated by the French New Wave, for example, that developed on the ground of a theoretical reflection on film (Gorzo 2012, 266-267). Doru Pop shares this opinion claiming that Romanian New Wave is already represented by Pintilie, Daneliuc and Ciulei (Pop 2010, 20).

3 Andrei State writes about the ambivalent, metaphoric character of Mungiu's films that, despite an objectifying appearance represent exactly the opposite of the realist project $(2014,76-77)$. See more on this tendency the essay of Veronica Lazăr and Andrei Gorzo on Aferim!, praising the novelty of Jude's film in terms of its political criticism $(2014,301-312)$. 
below, Radu Jude's latest Aferim! participates in the same historico-political allegorical, even didactic discourse started by Pintilie at the beginning of the 1990s, with the aim to illuminate the historical background of a societal crisis generated by huge social inequalities and a persistent patriarchal structure. Just like in the case of Pintilie, this didacticism seems to reveal a self-assumed artistic responsibility to evoke events of a distant past in order to find solutions to the problems of the present. As Herbert Kitschelt points out in his methodological essay on post-communist social diversity, "in periods of societal crisis, people are capable of activating their long-term memory and scan its content in order to interpret their strategic options under conditions of uncertainty. Moreover, technical and institutional memory enhancers (scripture, literacy, media of communication, education, professionals in charge of preserving memories) (...) extend the capacity of human actors to retrieve and process information over lengthy periods of time" $(2003,62)$.

I argue that allegory has become a discursive mode capable of establishing a link between past and present by conferring new meanings to old signifiers, in an artistic effort to establish national values, circumscribe a national identity and character, as well as to thematize the position of the own country on the map of Europe. In this respect, a number of films by Lucian Pintilie made during the long and chaotic period of transition that followed the '89 events in Romania, do not simply display a continuation of a highly figurative artistic style that in the communist era was meant to mislead censorship. They rather serve as historical lessons highlighting recurrent situations in which under irrational, authoritarian leadership human values become endangered and are doomed to perish. Pintilie, the most distinguished representative of an older generation of Romanian filmmakers, now 82, and Radu Jude from the new generation of Romanian filmmakers with Aferim! apparently assume the task mentioned by Kitschelt, to retrieve distant memories from times that preceded the far too long communist era, but not in order to show up coping strategies, but rather to reveal the causes of the inexistence of such strategies. In the case of Pintilie, this attitude corresponds to a political standpoint represented by the independent, non-governmental association called The Group for Social Dialogue (Grupul pentru Dialog Social), of which he used to be an active member. The political program of this association reuniting prominent personalities of the Romanian cultural life proposes to defend and promote democratic values, human rights and liberties, as well as to reflect critically on fundamental problems of the Romanian society. I contend that all three films by Pintilie under analysis can be seen as allegorical discourses contributing 
to this social dialogue around the difficulties of a Romanian implementation of democratic, European values. They represent three distinct moments of Romanian $20^{\text {th }}$ century history that can be seen as allegories of a national destiny impossible to overcome: An Unforgettable Summer ( $O$ vară de neuitat, 1994), set in the Romania of the first decades of the $20^{\text {th }}$ century (a few years after the formation of Greater Romania, incorporating Transylvania, Bukovina and Bessarabia) tells the story of the family of a Romanian officer, exiled to the politically unstable border with Bulgaria, because he refuses to accept the way one of his superiors approaches his wife, a charming, sensitive woman with Hungarian and Romanian ancestry and Western education (played by Kristin Scott Thomas). The short film entitled Tertium Non Datur (2006) presents an official meeting between two German officers and their Romanian allies during the Second World War, consisting of a single, highly dramatic scene in which what was meant to be a strategic discussion turns into a humiliating situation for the Romanian party. Too Late (Prea târziu, 1996) is set in the late 1990s, a few years after the infamous second revolt of the miners, in a mining area facing mysterious murders and the danger of apparition of a new type of man, the so-called "sub-human."

These films can be seen as historico-political allegories that manage to avoid "provinciality," that is, to provide meaning not only on the narrative level, a story well known by the natives (as Temenuga Trifonova characterizes the allegorical expressionism of Bulgarian films). As I will argue below, visual figuration is crucial in Pintilie's films in the creation of a universal discourse on endangered human and democratic values. In what follows, I propose to analyze the manifold roles of intermedial references in these films, ranging from narrative and poetical to more sophisticated, philosophical, ideological or discursive ones. These mainly pictorial or sculptural references to either specific works of art or a certain visual art (painting, photography, sculpture) as system (colours, lighting effects, composition, style), ${ }^{4}$ besides their immediate figurative role in the respective narrative, tend to function as separate, autonomous discourses of the artistic creation and often of the socio-political context of the film in question. As such, they often appear as an excess to the reality, reveal something that can only be shown, not verbally formulated or narrated, thus qualify for what has been termed "the figural" by Jean-François Lyotard, Gilles Deleuze or more recently by D. N. Rodowick. ${ }^{5}$ The interconnectedness of intermedial figuration with allegory is

4 See Irina Rajevsky's distinction between individual and system intermedial references $(2005,53)$.

5 See on this Lyotard's Discourse, Figure (2011), Deleuze's book on Francis Bacon (2004) and Rodowick's Reading the Figural (2001). 
enabled by allegory's inherent affinity with mediation and artificial signification. As Ismail Xavier points out, "allegory has come to the foreground, and one strong reason for its reawakening in modern times is the fact that it has always been the signifying process most identified with the presence of mediation, with the idea of a cultural artifact that requires specific frames of reference to be read, quite distant from any sense of the "natural'" $(2004,333)$.

In Pintilie's films, visual clues ensure the transcendence of the narrative meaning in an allegorical discourse that also enables the emergence of the figural, elevating actual signification to a discursive, theoretical level. The figurative language charged with intermedial references attracts theoretical discourses susceptible to illuminate the visual representation of cultural values in the context of political, historical crisis. Such a discourse appears in connection with historical and national allegory that, in line with Benjamin's concept of history seen not as a progress, but as a disaster, becomes an ingredient of what can be called "the spirit of our time," incompatible with the realist form and rather demanding a cognitive mapping of social phenomena. As Ismail Xavier in his interpretation of cinematic national allegories points out: "allegory has acquired a new meaning in modernity - more related to the expression of social crisis and the transient nature of values, with special emphasis given to its connection with the sense of the fragmentation, discontinuity, and abstraction provided by compression of space and time in our contemporary technological world" $(2004,360)$.

The Outsider's gaze that Pintilie repeatedly adopts attracts another discourse concerned with national identity, otherness and self-othering. Based in France, he often uses Western art references - music, painting or sculpture to ironically depict a post-communist Romanian society ignorant of individual dramas resulting from the collapse of industry, economy and infrastructure. He repeatedly thematizes institutional miscommunication, coexisting with a preference for Western cultural and civilisatoric forms without content. This paradoxical attitude of the insider-outsider can be best described with Homi Bhabha's concept of colonial mimicry, defined as "an ironic compromise animated by the desire for a recognizable Other, the subject of a difference that is almost the same but not quite (not white)" (1994, 86). Finally, in some of Pintilie's films, the visual, discursive figuration of the crisis of societal values, that of national and individual identity, is realized with a visionary, spatial poetics of miniaturization. According to Gaston Bachelard, the miniature, while proving that the acts of fantasy are as real as those of reality, becomes the shelter of greatness by concentrating and enhancing values. Miniature is created by a 
vertical vision and a distance: as Bachelard puts it, from distance everything is neatly arranged, accessible and ready to be taken in possession $(1961,159)$. In these films, smallness figurates a far too big distance from core values and an urge for control, connected with a fear of devaluation and a growing national and individual inferiority complex. Although Pintilie's films and Aferim! do not present emblematic historical events, they are working with events, situations and characters susceptible for allegorical interpretation of national identities that, according to Xavier, emerge in a labyrinth of political ideologies and instability characteristic of Eastern European countries (2004, 359-60). Pintilie's films under analysis and Aferim! epitomize allegory as both "Thirdworldish" (as Jameson has controversially put it) and a mode of discourse attracting a "high" reflexive modernism (Xavier 2004, 335-336). This combination of depiction of a local, Eastern-European crisis with the discursive practices of modernism can be best identified in visual compositions establishing an intermedial dialogue with an Orthodox Christian iconography and the cultural codes it represents.

\section{Orthodox Christian Iconography and Allegorical Signification}

In the light of the new meanings acquired by allegory, discussed by Xavier, the allegorical films of Pintilie and other Eastern European directors refuse to provide humanity with an aesthetic redemption of the world in perfect forms, "rather interacting with historical fractures and violence, especially when observed from the point of view of the defeated" (2004, 346). For the defeated, in this case the Eastern European nations, history is not seen as a progress, but rather as a repetition of a long line of frustrating events that cannot be fully compensated with the Christian belief in a cosmic order that endows human history with internal logic (Xavier 2004, 342). Accordingly, unlike Christian allegories revealing destinies of salvation where every pain had a meaning, the films under analysis show pain and humiliation as meaningless, not connected with historical or social progress whatsoever. Moreover, the defense of Christian and human values is not connected with redemption or reward: the protagonists fail, become alcoholic, migrate to the West and lose faith in everything. The allegorical superimposition of timeless truths of the Christian faith with the historicity of human experience is recurrent in scenes depicting interactions of the protagonists with representatives of the Orthodox Church, for example in Mungiu's Beyond the Hills and Jude's Aferim!. These instances work with 
stereotypes, constant ingredients of allegories, as in them, according to Xavier, a social group finds its "illustration" or embodiment in a single image or narrative specially composed to confirm that false generalization. Orthodox priests, just like doctors, officers and representatives of the law (policemen, constables) can be seen as personifications of questionable moral values in national allegories provided by these films, their reading strategies depending heavily on the sociopolitical context of the reading itself (Xavier 2004, 341).

The socio-political role of Christianity, and in the particular case of Romania, that of the Orthodox Church, is represented as a purely formal one in compositions reminding of Byzantine iconography and implying cultural codes specific of Romanian society. Besides stereotypical narrative situations, characters and dialogues, there is a recurrent visual feature in the post-communist Romanian film, a composition with three figures in a scene staging the mechanisms of authority. But this authority - represented by doctors, police officers, priests or TV managers - is regularly revealed as empty, a "form without content" (Boia 2012, 38). Cristi Puiu in the production notes to The Death of Mr. Lăzărescu points out his and his co-scriptwriter Răzvan Rădulescu's preference for scenes with three characters: "Two people talk, the third person mediates. But I also find that this triangular relationship does not work at all." ${ }^{\circ}$ The scene with three characters finds its visual abstraction in many films of the new Romanian cinema: Doru Pop is the first to point out the affinity of this triangular composition with the Orthodox Christian iconography representing the Holy Trinity, more specifically Andrei Rublev's Troitsa (1425-1427) [Fig. 1]. In his interpretation of the closing scene of Police, Adjective (Polițist, adjectiv, Cristian Porumboiu, 2009) Pop emphasizes an obvious transformation of the religious Trinity in a reversed, mundane "trinity" $(2010,37)$. This representation of an authority without content through an act of de-sacralization or profanation resonates with Xavier's statement about "overall cultural systems" (in this case archaic religious formalities) outliving the material defeat of their subjects $(2004,334)$. These iconographical references do not simply figurate the role of a formal authority that the Orthodox Church represents in Romanian society, but participate in a wider allegorial, critical discourse on the forms without content in post-communist Romania. These can be detected, according to Boia, in various aspects of Romanian society, including informal (coping) strategies, clientelism, authoritarianism, attachment

6 Interview with Cristi Puiu on the site of Balkan Black Box festival, quoted by Diana Popa (2011, 120). See also Popa's analysis of a representative scene from The Death of Mr. Lăzărescu, where the failure of communication between three people is also revelatory of a powerless authority (Popa 2011, 120-125). 
to symbolic leaders, the habit of submission that is fought only with passive resistance (2012, 38-41). In this respect I find illuminating another reference of this tripartite composition, emphasizing the formal, authoritative influence of Eastern Christianity and revealing, at the same time, the patriarchal, hierarchical structure of Romanian society. These images can also be interpreted as allusions to the icons depicting the three patriarchs or three hierarchs of the Byzantine Church, Basil the Great, Gregory the Theologian and John Chrysostom. They played pivotal roles in shaping Christian theology, by providing explanations to religious theses and laws, as well as a moral example in faith and purity. They are represented with gospel books and scrolls that stand for guidance in Christian faith [Fig. 2]. Intriguingly, in Romanian films this composition often appears in situations where protagonists - representatives of the Church, Police or Justice - are facing a hard decision, a conflict between human values and institutional rules, and try to explain, clarify, implement laws in order to protect authority and to avoid anarchy and chaos. In Mungiu's Beyond the Hills, for example, the presence of the visiting girl is against monastic rules and her disruptive behavior is feared to undermine the stability of a community in formation. The scenes in which the protagonists debate the conditions of the outsider's stay show the same triangular composition [Fig. 3]. This visual model illustrates even more elaborately the discourse on an empty authority in Porumboiu's Police, Adjective, a film epitomizing what Andrei State terms as "semantic realism." As State points out, consciousness and law are recurrent terms in the film that appear in various contexts and configurations, in turns with denotative and figurative meanings, slipping between different, legal, philological and police registers $(2015,84)$. In the last scene of the film, concluding a long process of observation and formal (empty) reporting, three policemen take a decision in the case of three teenagers smoking marihuana, stiffly relying on the explanation of the word "consciousness" in the dictionary. Their position in the triangular composition clearly defines a power relationship (with the commanding officer in the middle), ensured by the possession of terms, rigid terminology and taken for granted knowledge. While the explanatory, patronizing style and quest of meaning is figurated in a Byzantine iconographic composition, the disruptive standpoint of the young detective, who does not want to ruin the youngsters' life only because they smoke pot, is represented by a modern, Western European pictorial reference, free from a semiotics of authority: a still life, a plate with

$7 \quad$ State talks about "realisms" in the case of New Romanian Cinema and specifically that of Porumboiu, distinguishing between situational, semantic and conceptual realisms (2014, 80-87). 
fruits in the middle of the table separating the protagonists [Fig. 4]. Ágnes Pethő identifies in this rigid, tableau-like scene an "abstract theatre" in which the bowl activates "a touch of the deadpan humour based on incongruities" $(2015,56)$. The profanation of the spiritual meaning of the Byzantine iconography, originally depicting eternal truths and values (here represented by a purely semantically defined law), is also emphasized by the intrusive presence of this different pictorial tradition focusing on the detail, the "here and now," the very materiality, transitory quality of the items depicted, or simply: life.

This spiritual-material duality is a common ingredient of the Byzantine style that Schraeder in his book Transcendental Cinema detects in films of Robert Bresson. He quotes Barthélémy Amengual, who describes Bresson's style as a "dialectic between concrete and abstract, the proximity, almost the identity, of the sensual and the spiritual, of emotion and idea, of static body and mobile mind" (Schraeder 1988, 99). Apart from the tripartite composition and the sensual-spiritual opposition, the films of the Romanian New Wave often share other striking features of the Byzantine iconography already detected in Bresson's minimalistic cinema by Schraeder, namely frontality, non-expressive faces, hieratic postures, "the long forehead, the lean features, the closed lips, the blank stare, the frontal view, the flat light, the uncluttered background, the stationary camera" that make these protagonists "objects suitable for veneration" (1988, 100). But Porumboiu's film, while representing the static body and the focused, immobile gaze of the detective watching the movements of the teenagers in long real time scenes, also exemplifies the ways the trajectories of a mobile mind get short-circuited by an authority sticking to empty terminologies. This feature resonates with Schraeder's remark on Byzantine iconography, seen as a purely formal function of the liturgy, where "[t]he individual became absorbed into the collective order, the collective order hardened into a form, and the form expressed the Transcendent. Consequently, the icons became stylized, rigid hierarchical, further and further apart from the world of verisimilitude and sensation" $(1988,98)$.

This rigid, hierarchical structure serving a collective order that alienates individuals from each other is modeled in Jude's Aferim!, with its title already pointing at a formality applied from the exterior (a Turkish expression of recognition). In this Western Wallach set at the beginning of the $19^{\text {th }}$ century, the story of a local constable charged to capture a Gipsy (slave) fugitive, the encounters with the authority (religious and worldly) reflect upon the same empty form lacking a reliable substance. On the road at some point they (he and his 
son) are joined by a priest, who provides a quasi-theological explanation for the judgmental stereotypes reiterated in the film (misogyny, xenophobia, homophobia and antisemitism), while the triangular composition reflects, once again, upon a socio-political system that finds its articulation in superstition and religion, both serving political and class oppression (Lazăr and Gorzo 2014, 304-305) [Fig. 5]. Without being overtly political, through visual and verbal generalizations (an overwhelming use of proverbs reflecting on Romanian-ness and human condition in general) Jude's film engages in a very subtle way actual social discourses. In this respect it continues the cinematic tradition started with Pintilie's allegorical films from the 1990s, contradicting many critics' view on the new generation's Oedipal complex reflected in a full break with the "father figures." clue of tripartite compositions representing the mechanisms of authoritarian power relationships already appears in Too Late, in images showing the miners "lost" in the darkness of the mine. In a final denunciation of patriarchal order, we see them in a composition miming the icon with the patriarchs who "brought light into people's lives," then, with a turn of slapstick comedy characteristic of Pintilie's films, they appear covered in white cement and raised, as statues, above a grey crowd of miners [Figs. 6-7]. In the case of Pintilie these visual compositions also mediate between the theatrical and the filmic, in a mediahistorical reflection on the tableau vivant: in film, this preserves its original role to concentrate the dramatic meaning of a theatrical scene. An internationally recognized director of theatre, Pintilie uses these static images as a culmination of the drama, in the spirit of the $18^{\text {th }}$ century theatrical practice. ${ }^{9}$ At the end of the film the same composition reappears in the symbolic scene where the prosecutor releases the "sub-human" with two assistants, on the surface, in full light, against the instructions of his superiors.

These visual references participate in a national allegory not only by revealing the ineffectiveness of state institutions and of those who are meant to take leadership and show example, but also by means of personifications, when a single character or a community is taken as standing for the entire nation. This is the case of the mining community in Too Late, exposed to the danger of moral and social devaluation and becoming sub-human (a concept illuminated by the proxemics of the film, showing, in a rather pedagogical way, a repetitive descent deep into the mine) after the collapse of the communist industry. The same

8 See on this Doru Pop (2010, 29-30).

9 On the affinities of the tableau with theatre and film see Steven Jacobs' Framing Pictures (2011, 88-89). 
applies to the family exiled to the Southern border in An Unforgettable Summer, a figuration of the liminal position of Romania in the European community and its imminent Balkanization. This vision can be traced back to a historical critical attitude of the other two principates (Transylvania, Moldavia) to the Byzantinism of Walachia, the three forming today's Romania. As Lucian Boia argues, these tensions are paired with a paradoxical relationship to foreigners and Western Europe, oscillating between xenophobia and a wish of imitation of a Western European cultural production. Lucian Pintilie's films that followed the regime change often thematize this identity crisis with allegories in which art references figurate the attitude assuming its image of "the Other" of Europe.

\section{Figurations of the Self-Othering Attitude}

As Ismail Xavier points out, intermedial references revealing the intimate connections between forms of representation and specific social conjunctures express in contemporary Eastern European films the labyrinth of political ideologies and national identities that shape the contemporary history in these countries suffering from a chronic instability. He also emphasizes the new trend of storylines involving multi-national encounters of protagonists who belong to distant cultures but are led to an unexpected interaction, most of the time of a clearly private nature, in mostly international co-productions that engage different European countries (2004, 360). An Unforgettable Summer and Tertium Non Datur depict such types of encounters, in which national identity is shaped through the Western gaze and a self-othering process.

Lucian Boia (2012) describes the remarkable imitative performance of Romanian artists as symptomatic of a national attitude venerating Western (mostly French) culture, without, however, reaching its standards. National painters like Nicolae Grigorescu, Ion Andreescu, Gheorghe Aman and Ştefan Luchian, some of them manifesting strong French influence, are remarkable but not exceptional, not reaching the level of a Gauguin or Cézanne. In order to turn this urge for imitation into mimicry, slippages and excesses are needed to affirm the difference of Homi Bhabha's already mentioned "recognizable other" $(1994,86)$. While imitation loses itself in the process, mimicry characterizes by a partial representation and a double vision that subverts colonizing, narcissistic authority (in this case the French artistic influence) through excesses and an ironical affirmation of difference (1994, 88). The celebration of national identity while assuming one's difference, the ability to elevate the particular and provincial to the status of allegorical and 
universal is a rare artistic competence, represented by few Romanian artists: the works of Mircea Eliade, Emil Cioran, Tristan Tzara, Constantin Brâncuşi and, we can add, Lucian Pintilie, testify for colonial mimicry as self-affirmation through ironical and partial imitation, repetition of European models and discourses. The double vision over Romanian identity of the insider-outsider - of Romanian artists settled and becoming famous in France - is epitomized by the work of Brâncuşi, who is considered the father of modern sculpture, with works of art mixing abstract geometrical forms with Romanian folklore motifs. In a similar vein, while adhering to a European arthouse cinematic tradition and its figurative tendencies, Pintilie never misses to anchor his discourse in the Romanian social reality. In his films, Western art references usually become catalysts of the selfothering process: in Too Late, An Unforgettable Summer and Tertium Non Datur they also participate in allegories of loss of humanity and (Western, democratic) values amidst barbaric and de-humanizing social conditions. Not surprisingly, some of these references are the works of Constantin Brâncuşi, depicting humanistic values like individual freedom, love, spiritual emancipation, evoked in narrative contexts of war and social restlessness. In An Unforgettable Summer, for example, in the childhood memories of a voice over narrator, the mother of Central and Eastern European origin, but educated in England, a woman of a remarkable artistic sensitivity, beauty and kindness, who follows her officer husband to the Romanian-Bulgarian borders in a mission to control Bulgarian insurgents, is shown in the pose of Brâncuşi's Sleeping Muse (1910), just before traumatic, inhuman events destroy family peace [Figs. 8-9]. This reference can also be interpreted as the figuration of a counter-colonization represented by the work of Brâncuşi, of the Eastern gaze turned back onto the colonizer (Pintilie's camera capturing British actress Kristin Scott Thomas's body), as well as a dissolution of East-West differences through art and beauty.

In this allegory of Romania's liminal geopolitical position in Europe, family becomes "the exemplary microcosm that condenses the entire nation" (Xavier 2004, 357), a society where frustration stemming from useless fights with phantasmatic enemies at the borders (figurated by the Bulgarian partisans in the film) counteracts the integration process in a post-revolutionary, optimistic New Europe. The mother is the personification of a welcoming, even idealistically colonizing Central-Western European attitude: she decides that she likes the deserted place, calls the neighboring hill the Fujiyama and fills the rooms with singing and piano play from operas by Mozart. The diegetic music has a similar figurative role in Too Late, where four young, idealistic students from the capital 
city come to the mining area in order to bring hope to desperate people living amidst inhuman conditions and poverty. They settle at the entrance of the mine, playing string quartets by Schubert, but fail to stop the crimes and the collapse of the whole industry and of the respective community, a metaphor of the Romanian society of the 1990s. One of them, a girl, even falls victim to the barbaric events she witnesses: the opening and final scene of the film shows her in a metro tunnel (a kind of replica of the mine) playing cacophonic music with her long hair in her face, in a disturbed state of mind similar to the mother's in An Unforgettable Summer.

In fact, both the reference to Brâncuşi's Sleeping Muse and classical music can be read as a figuration of a brief, euphoric encounter between idealized and idealizing European and local moral and aesthetic values. In this respect this film is, together with other post-communist films of Pintilie, a cinematic version of a historical discourse represented by Lucian Boia, that aims to reveal the causes of Romania's difference from the rest of Europe. As he points out, Romania's image as a country where everything can happen and is difficult to make a difference between truth and lie, is a consequence of complex sociohistorical and geopolitical factors, such as its distance from the centres, culturalcivilizatoric developmental delays, a hereditary weakness of the state, instability generating power abuse, as well as hierarchical and patriarchal social structures. As we have seen, a similar artistic attitude appears in Radu Jude's Aferim!, twenty years after Pintilie's film: in an apparently changed political context - Romania became member of the European Union - this film chooses events from a $19^{\text {th }}$ century Walachia dominated by huge social inequalities as well as a Turkish and Greek influence, in order to allegorically illuminate a hierarchical contemporary Romanian society regressing to historical (Balkanic) models instead of following progressive democratic programs. In fact, Boia's book and Pintilie's allegories represent the same discourse of a growing number of Romanian intellectuals (many of them members of the Society for Social Dialogue) criticizing the political comedy of the country: its paradoxical and chaotic aspect, its lack of authenticity and credibility, the tradition of incorrect games discrediting institutions and laws (cf. Boia 2012, 59-108). This political background implies a strong inferiority complex combined with periodic outbursts of national pride that finds an inspired visual figuration in miniatures, most elaborately in Pintilie's (until now) last short film, Tertium Non Datur. 


\section{Miniaturization: Values under Reconstruction}

As a figuration of endangered values, in Too Late, on the table of the state attorney, reluctant to solve the case of mysterious murders in the mining area, there are miniatures of Brâncuşi's masterpieces, the Column of the Infinite, The Gate of the Kiss and the Table of Silence, looking fragile under a kitschy lamp that stands on a sturdy elephant-leg menacing to tramp over them, in a plastic figuration of how little Western European democratic and artistic values or local traditions count in the midst of socio-political anarchy [Figs. 10-13]. This image also alludes to the inferiority complex and loss of moral values of a society that does not appreciate progress and beauty or its intellectuals capable of ensuring the spiritual opening towards a democratic Europe. The two invasions of the miners in the capital city in the 1990s, evoked in the film through television documentaries, appear as a brutal force tramping over (beating up on the street) presumed intellectuals, men and women.

The use of miniature in Pintilie's film epitomizes Bachelard's thesis that the artistic imagination is capable of seeing the totality in the small, the individual drama and endangered cultural values exposed to great historical movements (1961, 157). According to Bachelard, the poet always sees the same thing, regardless of the microscope or telescope he uses: in the poetic vision resembling the augmenting gaze of children there is a constant transaction between small and grand: the microcosmos and macrocosmos are correlatives (1961, 157-159). The switch of scale in the image mentioned above confirms that the detail augments the objects, the miniatures exposed on the table becoming a shelter of (artistic) greatness and values (1961, 145-146). As Bachelard emphasizes, distance creates miniatures, but also isolates, revealing them as nests of solitude $(1961,159)$ : Pintilie also warns that the distance ensuring this Lilliputian vision is too big to grant the possession of values represented by the miniature. This distance concerns both sides: for Western Europe, Romanian contribution to a shared cultural heritage is almost unknown, while for Romanians democratic, Western cultural values remain inaccessible, simple forms without content.

In Aferim!, the marionette play seen by the constable, his son and the captured Gypsies (the adult and the kid) on their way back to the boyar's, reveals a similar reflection of the great in the small, as well as an artistic distantiation obtained through a mise en abyme solution: the puppet show as miniature reflects upon both the actual story and its protagonists, as well as contemporary Romanian society and its stereotypical characters. The traditional Romanian puppet show Mărioara 
and Vasilache, usually played in fairs and popular festivities, presents a cunning and intelligent character (Vasilache) who has the sympathy of the public despite being amoral, opportunist and disrespectful towards authority and women. ${ }^{10}$ This description fits more than one protagonist of the film who keep voicing their racist, misogynistic and xenophobic opinions throughout and subordinate everything to their social ambitions. Intriguingly, the puppet show also discloses a society preserved in infancy by patriarchal authorities that treat adults as children and children as adults: the Gypsy boy is sold as a slave at the very same fair.

The miniature as metaphor of a national identity in which acute complex of inferiority and excesses of national pride coexist, finds its most elaborate representation and central narrative function in Tertium Non Datur. Set during the Second World War, this is the anecdotic story of an official meeting between Romanian officers with their allies, a German officer and his assistant of Eastern European origin. But what was meant to be a strategic encounter turns into a humiliating situation that, in the end, prompts the Romanian participants to reconsider their national and individual pride and patriotism. The scene of intercultural exchange that Ismail Xavier considers typical for the European cinematic production of the last two decades $(2004,360)$ is an obvious allegory of Romania's negotiations with the European Union, before becoming a member in 2007, just a few months after the release of Pintilie's film. The two officers represent two different attitudes of the European Union towards Eastern Europe in general and Romania in particular: indifferent distantiation (the German general does not utter a word during the meeting, remains distant and expressionless) and the curiosity of the collector, attracted by an exotic other (the enthusiastic assistant of the general). During dinner it turns out that the young officer has in possession a rare Romanian stamp of a considerable value with a Moldavian crest on it, one of the two existing in the world. The stamp gets lost unexpectedly and in a highly emotional and dramatic scene the Romanian general orders his officers to undress full monty to prove that nobody has stolen the valuable object. Eventually, it turns out that the stamp got stuck to a plate, the guests take their leave, and one of the officers confesses that he actually owns the other stamp, a present from his mother, a cherished amulet meant to protect him in need. However, after the aforementioned, humiliating scene he chooses to burn the stamp, a miniature figurating privacy and national pride, but turned into an

10 It is worth mentioning that the marionette Vasilache appears in a contemporary Romanian novel as a figuration of the manipulated, brainwashed individual under communist dictatorship in Lucian Dan Teodorovici's Matei the Brown (2011). 
image of the "other" by an external, Western gaze [Figs. 14-15]. The title (Tertium Non Datur - 'no third option possible') uttered by the assistant of the general in Latin to emphasize the limited number of the rare stamp, can also be interpreted as a reference to the confrontation between the two identity discourses modeled in the film: the national, patriotic one and that of the self-assumed "otherness."

In the light of the analyses above and Ismail Xavier's theoretical approach, allegory comes to express the historicity of human experience and values in times of social crisis, serving, in the cultural production of post-communist countries, the process of self-understanding and re-invention of national identity. As I have shown, intermedial references - either to painting as system (composition, iconography) or to individual art objects - are central ingredients of this allegorical approach. Intriguingly, these references, even those to Western art, do not serve the dissolution of cultural boundaries between East and West, on the contrary, they are emphasizing difference. As Lucian Boia points out in his book Why is Romania different?, this alterity is mainly due to historical delay, an essentially patriarchal and hierarchical society and a merely formal adoption of Western values. As we have seen, the new generation of Romanian film directors manages to sublimate the identity crisis by assuming and thematizing difference in many award-winning films. By doing so, they also orchestrate, in line with Xavier's argumentation, the international affirmation of Romania through a cinema of "otherness" $(2004,352)$.

\section{References}

Bachelard, Gaston. 1961. Poétique de l'espace. Paris: Presses Universitaires de France.

Bhabha, Homi. 1994. Of Mimicri and Man. The Ambivalence of Colonial Discourse. In The Location of Culture, 85-93. London: Routledge.

Boia, Lucian. 2012. De ce este România altfel? [Why is Romania Different?] Bucureşti: Humanitas.

Deleuze, Gilles. 2004. Francis Bacon: The Logic of Sensation. London, New York: Continuum.

Gorzo, Andrei. 2012. Lucruri care nu pot fi spuse altfel: un mod de a gândi cinemaul, de la André Bazin la Cristi Puiu. [Things That Cannot Be Said in a Different Way: A Way of Thinking Cinema, from André Bazin to Cristi Puiu.] Bucureşti: Humanitas.

Jacobs, Steven. 2011. Framing Pictures. Films and the Visual Arts. Edinburgh: Edinburgh University Press. 
Kitschelt, Herbert. 2003. Postcommunist Regime Diversity. In Capitalism and Democracy in Central and Eastern Europe, eds. Grzegorz Ekiert and Stephen E. Hanson, 49-86. Cambridge: Cambridge University Press.

Lazăr, Veronica and Andrei Gorzo. 2014. Aferim! - ceva nou în cinemaul românesc Porumboiu [Aferim! - Something New in the Romanian Cinema]. In Politicile filmului. Contribuții la interpretarea cinemaului românesc contemporan [The Politics of Film. Contributions to the Interpretation of Contemporary Romanian Cinema], eds. Andrei Gorzo and Andrei State, 301-312. Cluj Napoca: Tact.

Lyotard, Jean-François. 2011. Discourse, Figure. Minneapolis, London: University of Minnesota Press.

Pethő, Ágnes. 2015. Between Absorption, Abstraction and Exhibition. Inflections of the Cinematic Tableau in the Films of Corneliu Porumboiu, Roy Andersson, and Joanna Hogg. Acta Universitatis Sapientiae: Film and Media Studies vol. 11: $39-76$.

Pop, Doru. 2010. The Grammar of the New Romanian Cinema. Acta Universitatis Sapientiae: Film and Media Studies vol. 3: 19-40.

Popa, Diana. 2011. Probing the Body - Political and Medical (Empty) Authority in the New Romanian Cinema. Acta Universitatis Sapientiae: Film and Media Studies vol. 4: 115-129.

Rajevsky, Irina O. 2005. Intermediality, Intertextuality, and Remediation. A Literary Perspective on Intermediality. Intermedialités no. 6. Automne: 43-64. Rodowick, D. N. 2001. Reading the Figural, or, Philosophy after the New Media. Durham and London: Duke University Press.

Schrader, Paul. 1988. Transcendental Style in Film. Ozu, Bresson, Dryer. New York: Da Capo Press.

State, Andrei. 2014. Realismele lui Corneliu Porumboiu [The Realisms of Corneliu Porumboiu]. In Politicile filmului. Contribuții la interpretarea cinemaului românesc contemporan [The Politics of Film. Contributions to the Interpretation of Contemporary Romanian Cinema], eds. Andrei Gorzo and Andrei State, 74-87. Cluj Napoca: Tact.

Trifonova, Temenuga. 2015. Contemporary Bulgarian Cinema: From Allegorical Expressionism to Declined National Cinema. In East, West and Centre. Reframing Post-1989 European Cinema, eds. Michael Gott and Todd Herzog, 127-146. Edinburgh: Edinburgh University Press.

Xavier, Ismail. 2004. Historical Allegory. In A Companion to Film Theory, eds. Robert Stam and Toby Miller, 333-362. Oxford: Blackwell Publishing. 


\section{List of Figures}

Figures 1-2. Reminiscences of Byzantine, triangular iconograpy in the New Romanian Cinema: reference to Andrei Rublev's Troitsa (1425-1427) and the iconic representation of the three patriarchs.
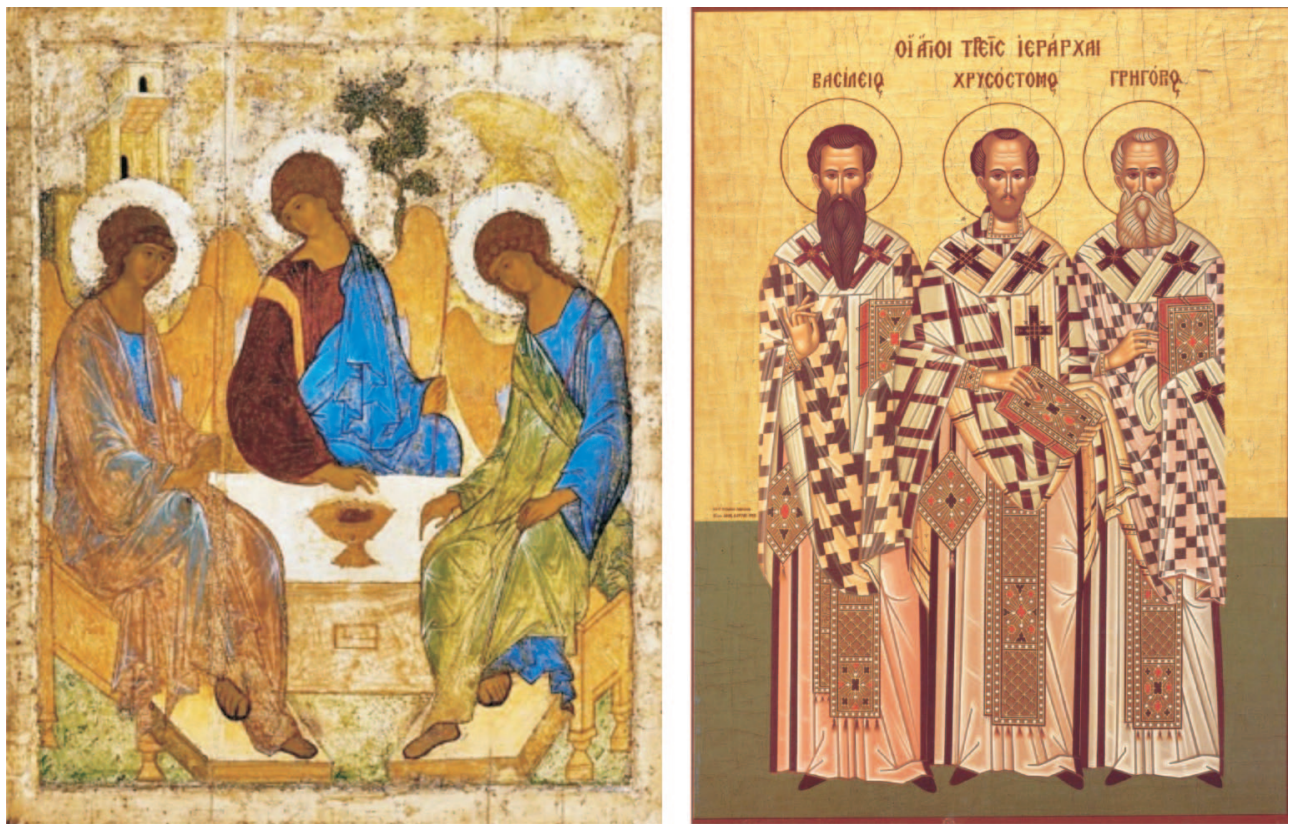

Figures 3-4. Byzantyne iconography as reference in situations of hard decision and implementation of rules (Beyond the Hills, Cristian Mungiu, 2012), reflecting on an empty authority (Police, Adjective, Cristian Porumboiu, 2009).
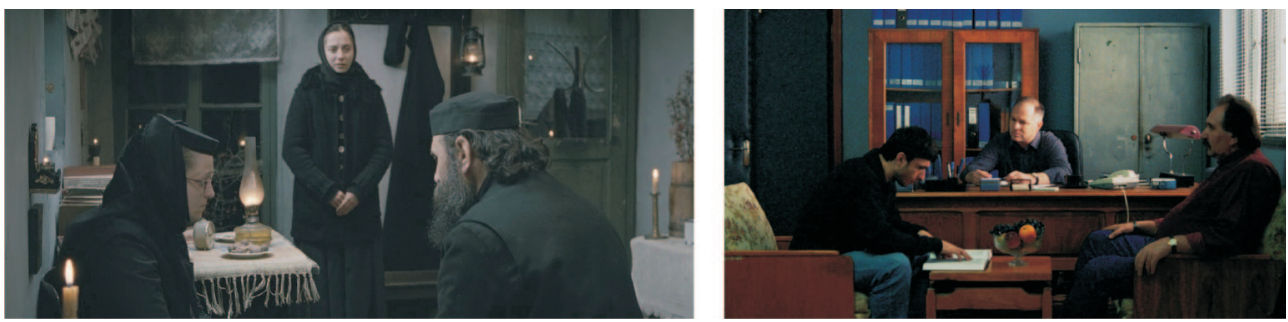
Figure 5. Triangular composition used in a pseudo-theological conversation in Radu Jude’s Aferim! (2015)

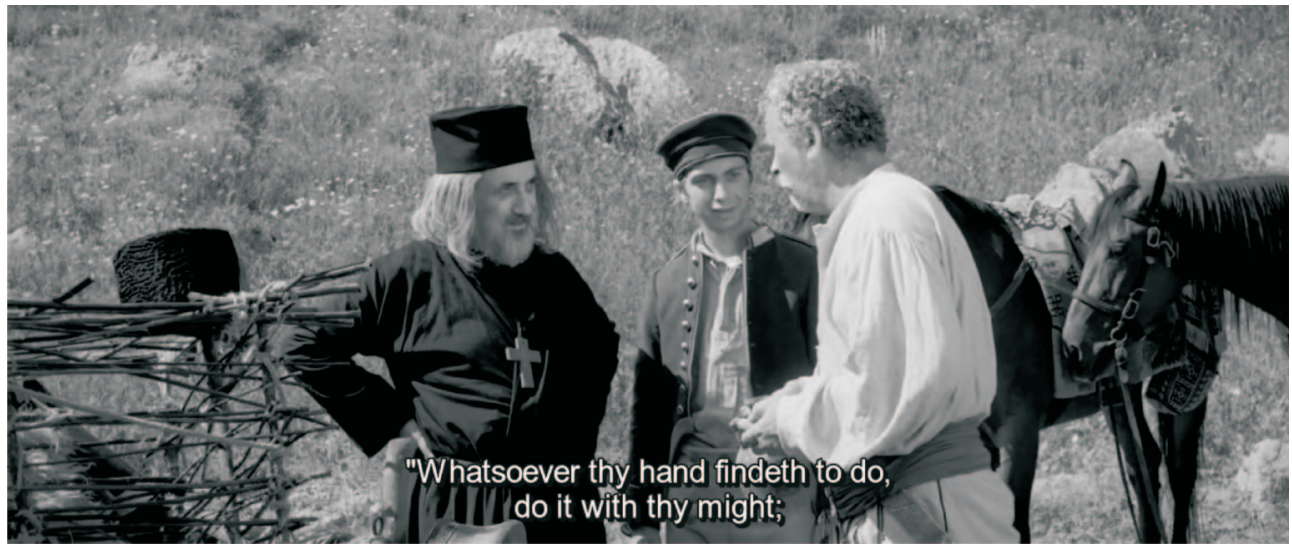

Figures 6-7. The debilitating effect of an authority keeping the population in the dark, conveyed with ironical theatricality inside triangular compositions in Lucian Pintilie's Too Late (Prea târziu, 1996).
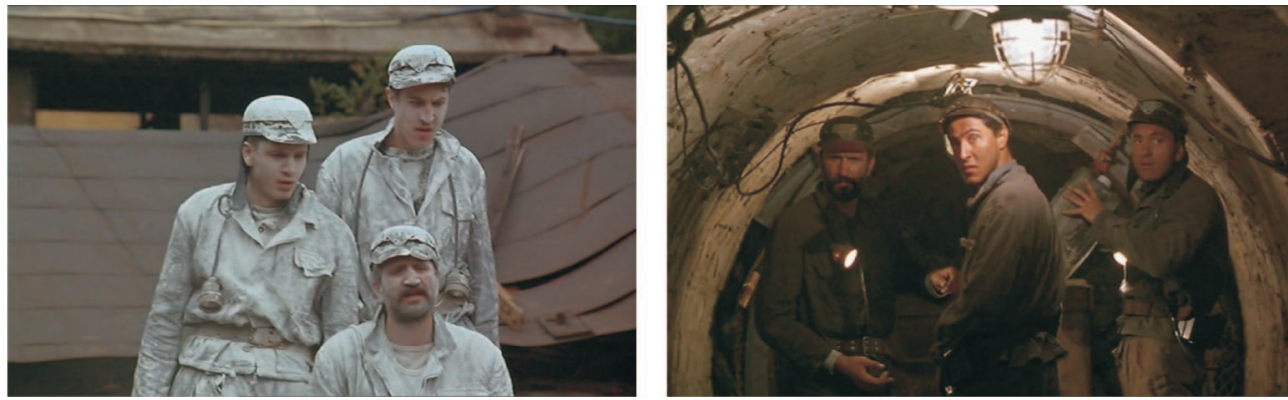

Figures 8-9. Reference to The Sleeping Muse of Constantin Brâncuşi in An Unforgettable Summer ( $O$ vară de neuitat, Lucian Pintilie, 1994), a figuration of endangered (European) values.
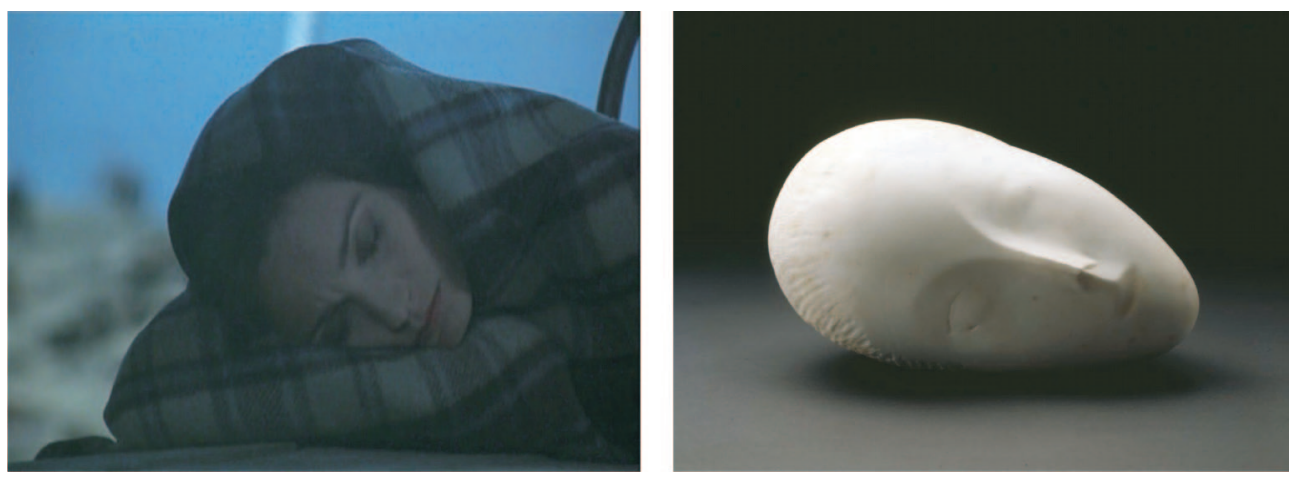
Figures 10-13. Kitschy miniatures of Brâncuşi's masterpieces on the table of the politician in Too Late (Prea târziu, Lucian Pintilie, 1996), standing for a provincial degradation of universal ideals and values.
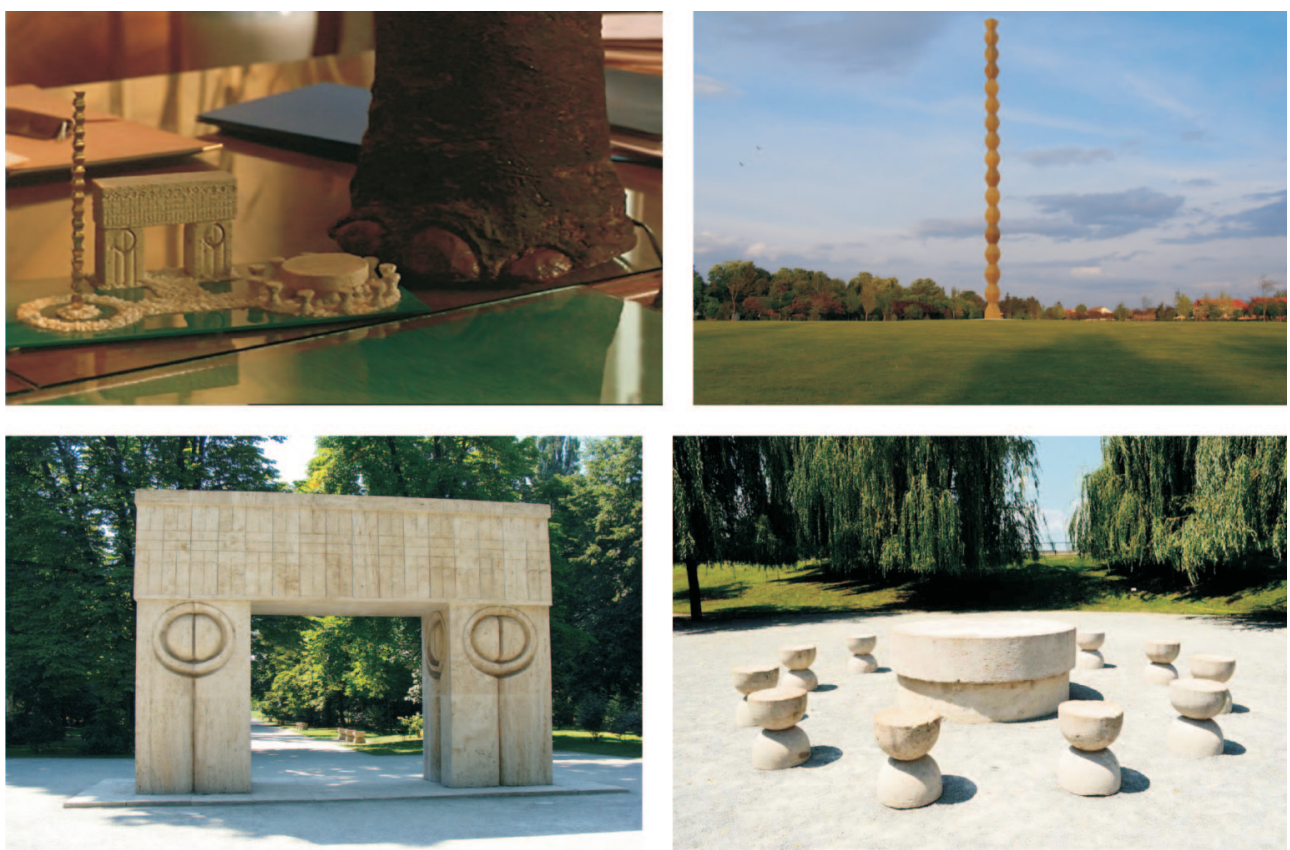

Figures 14-15. The miniature (the stamp) as figuration of two different discourses on national identity in Tertium Non Datur (Lucian Pintilie, 2006).
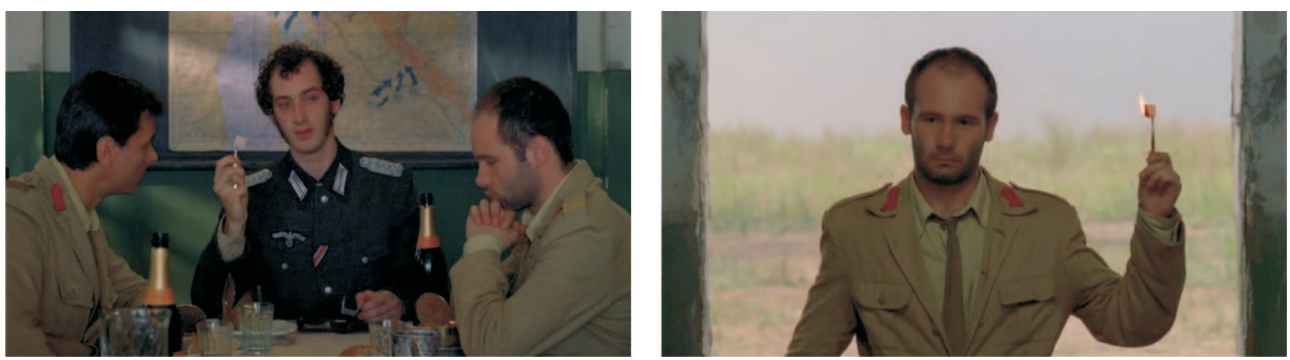